\title{
The lipid A biosynthesis deficiency of the Escherichia coli antibiotic-supersensitive mutant LH530 is suppressed by a novel locus, ORF195
}

\author{
Laura Hirvas, ${ }^{1}$ Marjatta Nurminen, ${ }^{1}$ Ilkka M. Helander, ${ }^{2}$ Riitta Vuorio' \\ and Martti Vaara'
}

Author for correspondence: Laura Hirvas. Fax: +3584346382.

e-mail: Hirvas@,cc.Helsinki.Fi

\footnotetext{
1 Department of Bacteriology and Immunology, Haartman Institute, PO Box 21 (Haartmaninkatu 3), SF00014 University of Helsinki, Helsinki, Finland

2 Department of Bacterial Vaccine Research and Molecular Biology, National Public Health Institute, Mannerheimintie 166, FIN-00300 Helsinki, Finland
}

\begin{abstract}
A new mutant of Escherichia coli K-12 supersensitive to both hydrophobic and large hydrophilic antibiotics was isolated and characterized.The mutant grew well at $28^{\circ} \mathrm{C}$, poorly at $37^{\circ} \mathrm{C}$, and did not grow at $42{ }^{\circ} \mathrm{C}$. The rate of its lipid A biosynthesis was reduced as compared to that of the parent strain. This deficiency was rescued by a novel locus, ORF195, the function of which has not been elucidated. ORF195 is located in the 76 min region in the $E$. coli chromosome and encodes a hypothetical $21.8 \mathrm{kDa}$ protein with no signal sequence. ORF195 isolated from the mutant strain had an identical sequence to the wild-type allele, indicating a suppressor function of the gene product.
\end{abstract}

Keywords: Escherichia coli, ORF195, lipid A, antibiotic-supersensitive mutant, permeability mutant

\section{INTRODUCTION}

The outer membrane (OM) of Gram-negative enteric bacteria functions as an effective permeability barrier (for reviews, see Nikaido \& Vaara, 1985, 1987). Hydrophobic and large hydrophilic compounds are effectively excluded due to lipopolysaccharide (LPS) molecules that are joined electrostatically by $\mathrm{Mg}^{2+}, \mathrm{Ca}^{2+}$ and polyamines to form a rigid and stable outer leaflet (Nikaido \& Vaara, 1987; Nikaido, 1990; Koski \& Vaara, 1991). Although the structure of the OM of Escherichia coli and Salmonella typhimurium is quite well known, its biogenesis is poorly understood as are many structurefunction relationships. Furthermore, the biosynthesis of lipid A, the essential component of LPS, has not been fully elucidated (Raetz, 1990, 1993; Schnaitman \& Klena, 1993; Young et al., 1993; Clementz et al., 1995), and the regulation of the biosynthesis pathway and the final steps of assembly and translocation of LPS are unclear.

Mutants supersensitive to antibacterial agents have been useful in characterization of the barrier function of OM. Heptose-deficient deep-core LPS mutants of $S$. typhimurium and E. coli are the most studied (for reviews, see Nikaido \& Nakae, 1979; Nikaido \& Vaara, 1985; Vaara, 1993). Many supersusceptible mutants harbour defects in lipid A biosynthesis genes. Such mutants include the $l p x A$ and $l p x D$ mutants of $S$. typhimurium and E. coli (Sukupolvi et al., 1984; Hirvas et al., 1991a; Vuorio \& Vaara, 1992a, b; Vaara, 1993). Some other supersusceptible mutants, such as the acr $A$ mutant of $E$. coli, have recently been shown to be defective in efflux pump systems (Ma et al., 1995). The biochemical defects of many other antibiotic-susceptible mutants, such as the SSB and $l k y D$ mutants of $S$. typhimurium and the abs mutant of E. coli, have not yet been elucidated.

As antibiotic-susceptible mutants have been shown to be valuable in studies of $O M$ biogenesis, we isolated a new set of supersensitive $E$. coli mutants. Here we describe one of them, E. coli LH530. The mutant is supersensitive to several unrelated hydrophobic antibiotics and does not grow at high temperatures. We also show that it synthesizes remarkably reduced amounts of lipid A at higher temperatures. Furthermore, we report that these defects are suppressed by multiple copies of a previously uncharacterized gene, ORF195, located at $76 \mathrm{~min}$ on the E. coli chromosome. However, ORF195 isolated from the mutant strain has an identical sequence to the wild- 
type allele. This indicates that ORF195 has a suppressor function.

\section{METHODS}

Strains, plasmids and growth conditions. E. coli K-12 strain JM105 (Yanisch-Perron et al., 1985) was used as the parent strain for mutant isolation and also for the preparation of an E. coli gene bank. E. coli strain DH5 $\alpha$ (Hanahan, 1983) was used as the cloning host. The cloning vector was pUC19 (Pharmacia). The low-copy vector was pACYC184 (New England Biolabs).

The properties of the OM mutant strains SM101 ( $l_{p} x A$; Galloway \& Raetz, 1990), CDH23-213 (lpxD; Tsuruoka et al., 1988) and D21f2 ( $r f a$, LPS chemotype Re; Boman \& Monner, 1975), and their parents SM105 (lpx $\left.A^{+}\right), \mathrm{CDH} 23-210$ $\left(l p x D^{+}\right)$, and D21 $\left(r f a^{+}\right)$have recently been reviewed (Vaara, 1993).

Bacteria were grown in LB broth at $28^{\circ} \mathrm{C}, 37{ }^{\circ} \mathrm{C}$ or $42^{\circ} \mathrm{C}$. When necessary, antibiotics were added at the following concentrations: $100 \mu \mathrm{g}$ ampicillin $\mathrm{ml}^{-1}, 40 \mu \mathrm{g}$ tetracycline $\mathrm{ml}^{-1}$, $40 \mu \mathrm{g}$ chloramphenicol $\mathrm{ml}^{-1}$ and $30 \mu \mathrm{g}$ fusidic acid $\mathrm{ml}^{-1}$.

Mutagenesis and isolation of supersensitive mutants. Several cultures of JM105 grown overnight at $37^{\circ} \mathrm{C}$ were incubated with $0.5 \%$ diethyl sulfate for $30 \mathrm{~min}$ at $37^{\circ} \mathrm{C}$. Cultures were diluted $1 / 100$ and incubated overnight at $28^{\circ} \mathrm{C}$. Mutants supersensitive to a hydrophobic antibiotic, fusidic acid, were isolated by penicillin counterselection (Tamaki et al., 1971; Coleman \& Leive, 1979; Sukupolvi et al., 1984). Approximately $10^{8}$ cells $\mathrm{ml}^{-1}$ were grown overnight at $28^{\circ} \mathrm{C}$ in the presence of penicillin $\left(300 \mu \mathrm{g} \mathrm{ml}^{-1}\right)$, and fusidic acid $(30 \mu \mathrm{g}$ $\left.\mathrm{ml}^{-1}\right)$. Survivors were plated on LB plates. After growth at $28^{\circ} \mathrm{C}$ the plates were replica-printed onto three plates. One of the plates contained fusidic acid $\left(30 \mu \mathrm{g} \mathrm{ml}^{-1}\right)$ and was incubated at $28^{\circ} \mathrm{C}$. The other two plates lacked fusidic acid and were incubated at $28^{\circ} \mathrm{C}$ and $42^{\circ} \mathrm{C}$, respectively. Clones unable to grow in the presence of fusidic acid and at $42^{\circ} \mathrm{C}$ were picked for further studies.

Antibiotic susceptibility determinations and phage sensitivity testing. Antibiotic susceptibility determinations by the agar diffusion method (Hirvas et al., 1991a) were performed by using LB plates and antibiotic discs. The minimal inhibitory concentrations (MICs) of the antibiotics (E test; AB Biodisk) were measured as described previously (Vuorio \& Vaara, 1992a). Bacterial sensitivity to LPS-specific bacteriophages $\mathrm{C} 21, \mathrm{Br} 2, \mathrm{Br} 60$ and $\mathrm{Ffm}$ was determined by the drop-on-lawn method on LB plates (Wilkinson et al., 1972).

DNA manipulations. General DNA manipulations were carried out as described by Sambrook et al. (1989). Isolation of chromosomal DNA was done as previously described (Koski et al., 1989). Plasmid DNA was purified on Qiagen spin columns according to the manufacturer's instructions. Southern blotting was performed under alkaline conditions with positively charged nylon membranes (Boehringer Mannheim). Southern hybridization was done at $37^{\circ} \mathrm{C}$ in $5 \times$ SSC, $0.5 \%$ sodium dodecyl sulfate (SDS), $5 \times$ Denhardt's solution, $50 \%(\mathrm{v} / \mathrm{v})$ formamide. The hybridized filter was washed at room temperature in $4 \times$ SSC, $0.5 \%$ SDS for $1 \mathrm{~h}$. Autoradiography was carried out at room temperature for $2-12 \mathrm{~h}$. The $900 \mathrm{bp}$ Pstl-EcoRV fragment originating from plasmid pLH27 (see Fig. 2) was labelled by using a multiprime DNA labelling kit (Amersham) and used as a probe. Appropriate restriction fragments were cut out of the agarose gel and DNA was isolated as previously described (Hirvas $e$ t al., 1991b). DNA sequencing of double-stranded DNA cloned in
pUC19 was performed by robotic work station catalyst 800 (Applied Biosystems) using fluorescently labelled primers or fluorescently labelled dye terminators with respective sequencing kits supplied by Applied Biosystems. Reactions were analysed using an Applied Biosystems 373 Stretch Automatic Sequencer.

Construction of a chromosomal clone bank. Chromosomal DNA was prepared from E. coli JM105, partially digested with Sau3A [approximately $0.12 \mathrm{U}\left(\mu \mathrm{g}\right.$ DNA) ${ }^{-1}, 37^{\circ} \mathrm{C}, 1 \mathrm{~h}$ ]. Fragments $5-10 \mathrm{~kb}$ in size were isolated and ligated into BamHI-digested pUC19 and treated with alkaline phosphatase. The ligated mixture was used to transform E. coli DH $5 \alpha$. Transformants were selected on LB plates containing ampicillin. Approximately 8000 transformants were pooled and plasmid DNA was extracted from this pool.

Isolation of complementating clones from the gene bank. Part of the plasmid DNA of the bank was used to transform competent cells of the supersusceptible mutant LH530. The transformation mixture was plated onto LB plates containing fusidic acid $\left(30 \mu \mathrm{g} \mathrm{ml}^{-1}\right)$. Three clones which were repeatedly able to grow on fusidic-acid-containing plates were found. To confirm that these clones were not chromosomal revertants of LH530, plasmid DNA was isolated from the clones and once again introduced into LH530.

Isolation of ORF195 from E. coli LH530. Chromosomal DNA isolated from strain LH530 was digested with $B g l$; end-filling by Klenow was followed by $S p h$ I digestion and the fragments were run on $0.8 \%$ agarose gels. Fragments approximately $1 \cdot 8-2.2 \mathrm{~kb}$ in size were isolated and ligated to SphI- and HincII-digested pUC19. The hybridization probe described above was used to detect the clone that carried ORF195. This plasmid was named pLH32.

Northern blot analysis. Total RNA was isolated from exponentially growing $\left(37^{\circ} \mathrm{C}\right)$ cells by the hot phenol method (VonGabain et al., 1983). The RNA was size-fractionated in formaldehyde gel containing $1.2 \%(\mathrm{w} / \mathrm{v})$ agarose (Sambrook et al., 1989) and transferred to zeta-probe membranes under mild alkaline conditions $(50 \mathrm{mM} \mathrm{NaOH})$. The blots were hybridized with the ORF195-specific probe. The EcoRV-HpaI fragment of $300 \mathrm{bp}$ that is completely internal to the ORF195 gene was labelled with $\left[\alpha^{-32} \mathrm{P}\right]$ CTP using a random priming kit from Stratagene. The hybridization was done at $42^{\circ} \mathrm{C}$ in $5 x$ SSC, $0.5 \%$ SDS, $5 \times$ Denhardts' solution, $50 \mathrm{mM} \mathrm{Na}{ }_{2} \mathrm{HPO}_{4}$ (pH 7.5), 50\% formamide. The hybridized filter was washed in $2 \times$ SSC, $0.1 \%$ SDS for $1 \mathrm{~h}$ and in $0.5 \%$ SSC, $0.1 \%$ SDS for $0.5 \mathrm{~h}$ at $42{ }^{\circ} \mathrm{C}$. The blot was imaged in a Bio-imagins analyser (Bas-1500, Fuji) and bound $\left[\alpha^{32} \mathrm{P}\right] \mathrm{CTP}$ was analysed and quantified by using the MacBas v. 2.x program (Fuji Photo Film).

Determination of the ratio of LPS to phospholipid biosynthesis. The ratio of LPS and phospholipid biosynthesis in LH530 and its derivatives was assayed (Vuorio \& Vaara, 1995) after labelling their fatty acids with radioactive acetate in vivo at $28^{\circ} \mathrm{C}, 37^{\circ} \mathrm{C}$ and $42^{\circ} \mathrm{C}$. In detail, $5 \times 10^{8}$ bacterial cells (from fresh $\mathrm{LB}$ plates grown at $28^{\circ} \mathrm{C}$ ) were suspended in $5 \mathrm{ml} \mathrm{LB}$ broth. After growing (with stirring) for $1 \mathrm{~h}$ at the selected temperature $\left(28^{\circ} \mathrm{C}, 37^{\circ} \mathrm{C}\right.$ or $\left.42^{\circ} \mathrm{C}\right), 10 \mu \mathrm{l}(0.74 \mathrm{MBq})$ $\left[{ }^{14} \mathrm{C}\right]$ acetate (sodium salt, CFA229, specific activity $1.89 \mathrm{GBq}$ mmol $^{-1}$; Amersham) was added and growth was continued for an additional $2 \mathrm{~h}$. The cells were harvested by centrifugation (4300 r.p.m., Heraeus megafuge), washed with $2.5 \mathrm{ml}$ saline, transferred with $1 \mathrm{ml}$ of saline into Sarstedt tubes $(1 \mathrm{ml})$ and collected by centrifugation. The phospholipids were extracted with two consecutive volumes of $750 \mu \mathrm{l}$ chloroform/methanol $(1: 2)$. The radioactivity of the extract was determined by measuring that of a $75 \mu \mathrm{l}$ sample in a liquid 
scintillation counter. From the remaining cell debris the esterlinked fatty acids of LPS were liberated by hydrolysis with $300 \mu \mathrm{l} 0 \cdot 17 \mathrm{M} \mathrm{NaOH}$ at $100^{\circ} \mathrm{C}$ for $1 \mathrm{~h}$. Thirty microlitres of $0.5 \mathrm{M}$ sodium acetate ( $\mathrm{pH} 5.0$ ) was added, the mixture was neutralized by adding $30 \mu \mathrm{l} 1.7 \mathrm{M} \mathrm{HCl}$ and converted to a twophase system by addition of $800 \mu \mathrm{l}$ chloroform/methanol $(1: 1)$. After low-speed centrifugation the lower phase was concentrated, dissolved in $50 \mu \mathrm{l}$ chloroform/methanol $(1: 2)$ and its radioactivity was measured. The result was multiplied by a factor of 1.5 , as one third of the fatty acids of LPS, the amide-linked ones, resist $\mathrm{NaOH}$ hydrolysis. The ratio of LPS to phospholipid biosynthesis was calculated by dividing the radioactivity of the LPS fraction (multiplied by 1.5 ) by the radioactivity of the phospholipid fraction.

Qualitative analysis of the lipid A by TLC. Bacteria grown in the presence of radioactive acetate as described above were subjected to extraction with chloroform / methanol $(1: 2)$. LPS residing in the pellet was hydrolysed to obtain lipid A $4^{\prime}$ monophosphate with $0.5 \mathrm{ml} 0.1 \mathrm{M} \mathrm{HCl}$ for $1 \mathrm{~h}$ at $100^{\circ} \mathrm{C}$ (Galloway \& Raetz, 1990), pelleted by centrifugation for $10 \mathrm{~min}$ at $15000 \mathrm{~g}$, dried and dissolved in $200 \mu \mathrm{l} \mathrm{methanol.}$ Samples of this preparation were analysed by TLC using silica gel 60 plates (Merck) and chloroform/methanol/water $/ 25 \%$ (v/v) $\mathrm{NH}_{4} \mathrm{OH}(40: 25: 4: 2$, by vol.) as solvent. The radioactive bands were visualized by autoradiography employing Kodak $\mathrm{X}$-omat film (Eastman-Kodak).

Isolation of the cell envelopes and SDSPAGE of OM proteins. Cell envelopes were isolated (Hirvas et al., 1991b) and their protein pattern was determined by SDS-PAGE $(15 \%, \mathrm{w} / \mathrm{v}$, acrylamide) (Laemmli, 1970). Gels were stained with Coomassie blue.

Computer analyses. Database comparison and manipulation of DNA sequences were performed using the programs contained in the University of Wisconsin Computer Genetics Group Package v. 8 (Madison, WI, USA).

\section{RESULTS}

\section{Isolation of supersensitive mutants}

E. coli JM105 was mutagenized with diethyl sulfate and cells sensitive to fusidic acid, a hydrophobic antibiotic, were enriched as described in Methods. Survivor cells on LB plates were replica-printed onto fusidic acid plates. Cells not able to grow on replica plates were picked for further studies. Their sensitivity to a set of hydrophobic

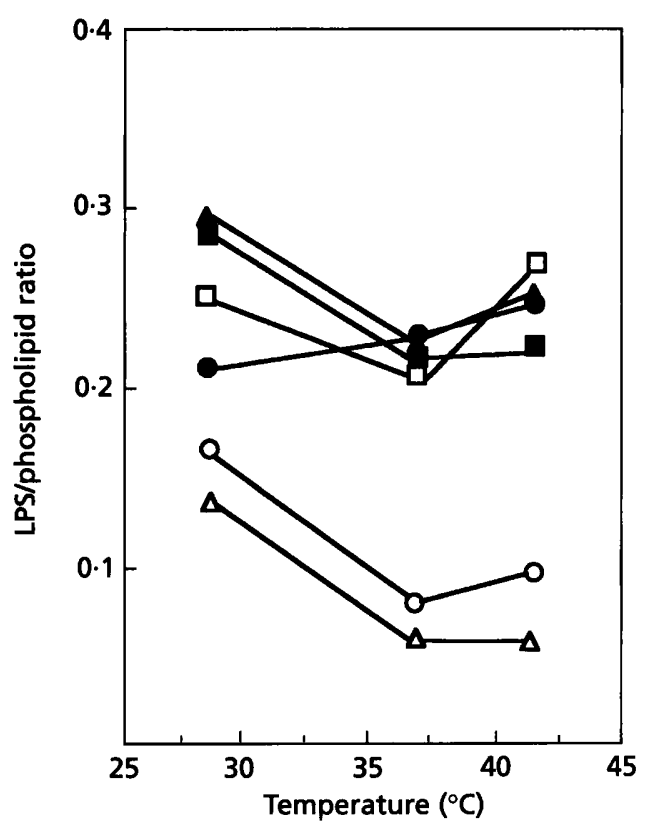

Fig. 1. The ratio of LPS to phospholipid biosynthesis at $28^{\circ} \mathrm{C}$ $37^{\circ} \mathrm{C}$ and $42{ }^{\circ} \mathrm{C}$ for E. coli LH530 (O), its parent JM105 (O) and its transductants carrying the plasmids pLH26 ( $)$, pLH29 (A), $\mathrm{pLH} 30(\triangle)$ and pLH31 $(\square)$.

and large peptide antibiotics was measured (data not shown). Ability to grow at $42{ }^{\circ} \mathrm{C}$ was also tested. About 30 thermosensitive and antibiotic supersusceptible mutants were obtained. Their sensitivity to LPS-specific bacteriophages ( $\mathrm{C} 21, \mathrm{Br} 2, \mathrm{Br} 60$ and $\mathrm{Ffm}$ ) was similar to that of $E$. coli JM105 indicating no alteration in the LPS core structure. However, the LPS/phospholipid ratio was decreased in most of the mutants (data not shown). One of the mutants, LH530, was chosen for further studies.

\section{Characteristics of E. coli LH530}

LH530 was sensitive to erythromycin, clindamycin, rifampicin and fusidic acid (Table 1), antibiotics that

Table 1. Susceptibility of LH530 and certain other OM mutants of $E$. coli and their parents to various antibiotics

\begin{tabular}{|c|c|c|c|c|c|c|c|c|c|}
\hline \multirow[t]{2}{*}{ Antibiotic } & \multicolumn{6}{|c|}{$\operatorname{MIC}\left(\mu \mathrm{g} \mathrm{ml}^{-1}\right)$} & \multicolumn{3}{|c|}{ Ratio* } \\
\hline & JM105 & LH530 & $\begin{array}{c}\mathrm{CDH} 23-210 \\
\left(\operatorname{lp} x D^{+}\right)\end{array}$ & $\begin{array}{c}\mathrm{CDH} 23-213 \\
(l p \times D)\end{array}$ & D21 & $\begin{array}{c}\text { D21f2 } \\
(r f a)\end{array}$ & $\begin{array}{l}\text { JM105/ } \\
\text { LH530 }\end{array}$ & $\begin{array}{l}\mathrm{CDH} 23-210 / \\
\mathrm{CDH} 23-213\end{array}$ & $\begin{array}{l}\text { D21/ } \\
\text { D21f2 }\end{array}$ \\
\hline Erythromycin & 50 & 1 & 30 & 0.50 & 30 & 0.75 & 50 & 60 & 40 \\
\hline Clindamycin & 30 & 1 & $\geqslant 256$ & 14 & $\geqslant 256$ & 3 & 30 & $\geqslant 18$ & $\geqslant 85$ \\
\hline Rifampicin & 10 & $0 \cdot 125$ & 10 & 0.016 & 10 & 0.25 & 80 & 625 & 40 \\
\hline Fusidic acid & $\geqslant 256$ & 4 & $\geqslant 256$ & 16 & $\geqslant 256$ & 32 & $\geqslant 64$ & 16 & 8 \\
\hline Vancomycin & $\geqslant 256$ & 24 & $\geqslant 256$ & 64 & $\geqslant 256$ & 50 & $\geqslant 10$ & 4 & $\geqslant 5$ \\
\hline Gentamicin & 1 & 0.75 & 1 & 1 & 1 & 0.50 & 1 & 1 & 2 \\
\hline Cefuroxime & 2 & $0 \cdot 38$ & 3 & 1 & 16 & 6 & 5 & 3 & 3 \\
\hline Ampicillin & 1 & $0 \cdot 25$ & 3 & 1 & 64 & 12 & 4 & 3 & 5 \\
\hline
\end{tabular}

* Approximate ratio between the MIC for the wild-type parent and that for the corresponding mutant. 


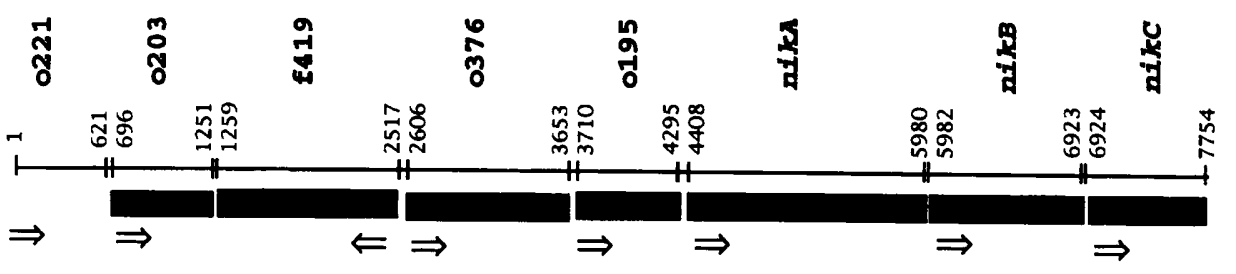

DHF26

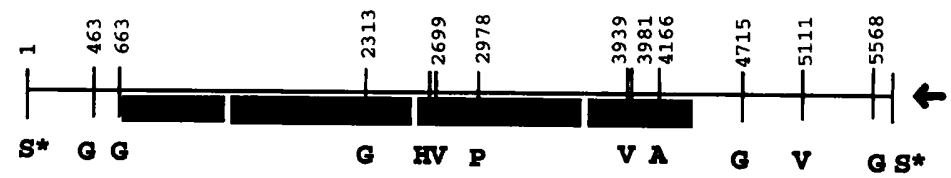

pLE27

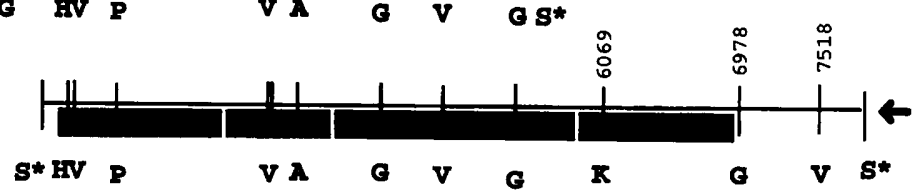

pHH28

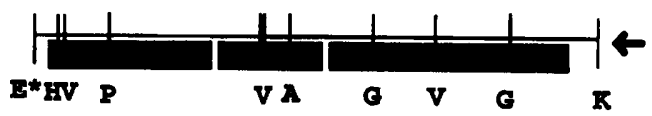

prit29

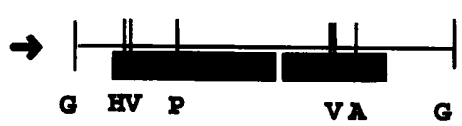

$\operatorname{pr} 30$

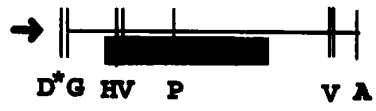

prin31

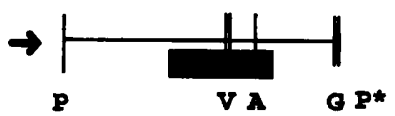

pLF32

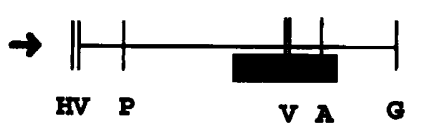

Fig. 2. The gene arrangement of the ORF195 chromosomal region and the fragments subcloned into pUC19. Numbers refer to distances in $\mathrm{bp}$. White arrows below the genes indicate the direction of transcription. Black arrows show orientation of the LacZ promoter of the pUC plasmid. Restriction sites: S, Sau3A; G, Bgll; V, EcoRV; P, Pstl; A, Accl; H, Sphl; D, HindIII; E, ECORI; and K, Kpnl. Sites marked with asterisks originate from the vector. Horizontal black bars are used to show entire genes or ORFs present in the plasmid constructions. The insert in pLH32 originates from LH530 whereas the inserts in all the other constructs originate from JM105.

traverse the $\mathrm{OM}$ via the hydrophobic pathway of diffusion (Nikaido \& Vaara, 1985, 1987). The MICs of these drugs were 30 - to 80 -fold lower for LH530 than for the parent strain, JM105, and were comparable with the MICs for the heptose-deficient D21f2 mutant (MICs 8to 85-fold lower) and the lpxD mutant CDH23-213 (MICs 16- to 600-fold lower). LH530 was also susceptible to the hydrophilic antibiotics vancomycin (Table 1) and bacitracin (data not shown), which are too large to penetrate the $\mathrm{OM}$ through porin channels. No sensitivity or only slight sensitivity was observed to gentamicin and cefuroxime; these antibiotics penetrate the OM through porin channels.

As seen by light microscopy, the cell morphology of LH530 differed from that of the wild-type, and some cells grew as long filaments at $28^{\circ} \mathrm{C}$ and $37^{\circ} \mathrm{C}$. Exponentially growing cells had normal $\mathrm{OM}$ protein composition at $28^{\circ} \mathrm{C}$ as demonstrated by SDS-PAGE (data not shown).

\section{The ratio of LPS to phospholipid biosynthesis in LH530 and its parent}

Bacteria were grown at $28^{\circ} \mathrm{C}, 37^{\circ} \mathrm{C}$ and $42^{\circ} \mathrm{C}$ in the presence of radiolabelled acetate, which is incorporated into the fatty acids of phospholipids and LPS. The radioactivities associated with LPS and phospholipids were measured separately, and the ratio of LPS to phospholipid biosynthesis calculated as described in Methods. In the parent strain, JM105, the LPS/ phospholipid ratio remained practically the same at all 
Table 2. Transcomplementation of E. coli LH530, SM101 (IpxA), and CDH23-213 (/pxD) with various plasmids

\begin{tabular}{|c|c|c|c|c|c|c|c|}
\hline \multirow[t]{2}{*}{ Strain } & \multirow[t]{2}{*}{ Plasmid } & \multirow{2}{*}{$\begin{array}{l}\text { Brief description of insert } \\
\text { (complete chromosomal } \\
\text { genes present) }\end{array}$} & \multicolumn{4}{|c|}{$\operatorname{MIC}\left(\mu \mathrm{g} \mathrm{ml}^{-1}\right)^{*}$} & \multirow{2}{*}{$\begin{array}{l}\text { Ability to grow } \\
\text { at } 42^{\circ} \mathrm{C}\end{array}$} \\
\hline & & & Fusidic acid & Rifampicin & Erythromycin & Vancomycin & \\
\hline LH530 & pLH29 & ORF376, ORF195 & 250 & 3 & 64 & $>250$ & + \\
\hline LH530 & pLH31 & ORF195 & $>250$ & 8 & 64 & $>250$ & + \\
\hline LH530 & pLH30 & ORF376 & 4 & 0.064 & 1 & 16 & - \\
\hline LH530 & pLH32 & ORF195 from LH530 & 250 & 4 & 32 & $>250$ & + \\
\hline LH530 & pGAH317 & $b l p A, l p x D$ & 8 & 0.25 & 2 & ND & ND \\
\hline LH530 & pRV40† & $\operatorname{lp} x A$ & 4 & $0 \cdot 25$ & 2 & ND & ND \\
\hline LH530 & pLH36ғ & $\begin{array}{l}\text { ORF376, ORF195 from } \\
\text { LH530 }\end{array}$ & 128 & $1 \cdot 0$ & 64 & 256 & - \\
\hline LH530 & pLH37 & ORF376, ORF195 & 128 & 1.0 & 24 & 96 & - \\
\hline $\mathrm{CDH} 23-213$ & pGAH317 & $b l p A, l p x D$ & $>256$ & 6 & 48 & ND & ND \\
\hline $\mathrm{CDH} 23-213$ & pLH31 & ORF195 & 8 & $0 \cdot 016$ & 0.75 & ND & ND \\
\hline SM101 & pRV40† & $\operatorname{lpx} A$ & $>250$ & $1 \cdot 0$ & 8 & ND & ND \\
\hline SM101 & pLH31 & ORF195 & 6 & 0.094 & 0.50 & ND & ND \\
\hline
\end{tabular}

ND, Not determined.

${ }^{*}$ MIC determinations were performed at $28^{\circ} \mathrm{C}$ (SM101 and $\left.\mathrm{CDH} 23-213\right)$ or at $37^{\circ} \mathrm{C}(\mathrm{LH} 530)$ on LB plates containing ampicillin (100 $\mu \mathrm{g}$ $\left.\mu \mathrm{l}^{-1}\right)$.

†Carries $l p x A$ in an approximate $6 \mathrm{~kb}$ insert from S. typhimurium SH5014 (Vuorio et al., 1994).

$\ddagger$ The inserts were cloned into the low-copy vector pACYC184.

temperatures, but in the mutant the ratio was $75 \%$ at $28^{\circ} \mathrm{C}, 35 \%$ at $37^{\circ} \mathrm{C}$, and $40 \%$ at $42{ }^{\circ} \mathrm{C}$ (nonpermissive temperature) of that in JM105 (Fig. 1).

\section{Qualitative analysis of lipid A of LH530}

The lipid A $4^{\prime}$-monophosphate patterns of LH530 grown at $28^{\circ} \mathrm{C}, 37^{\circ} \mathrm{C}$ or $42^{\circ} \mathrm{C}$ were identical with that of the parent strain and no lipid A precursors were found in chloroform/methanol extracts of the cells (data not shown).

\section{Complementation of the antibiotic-supersensitive phenotype of the mutant}

To identify the gene defective in LH530, we tested the ability of the E. coli JM105 chromosomal gene bank to complement the defect. Three plasmids were obtained able to complement the antibiotic susceptibility pattern and the thermosensitive phenotype. Two of the plasmids gave identical restriction patterns. Plasmids with different patterns were chosen for further analysis, and named pLH26 and pLH27 (Fig. 2). Partial restriction mapping showed that they carried inserts approximately $5.5 \mathrm{~kb}$ and $5.2 \mathrm{~kb}$ in size, respectively. Plasmids shared an overlapping segment of approximately $3.0 \mathrm{~kb}$ (Fig. 2 ). This segment was expected to include the complementing sequence.

An EcoRI-KpnI fragment, containing the overlapping segment of pLH26 and pLH27, was isolated from pLH27, subcloned into pUC19 and named pLH28 (Fig. 2). Part of the nucleotide sequence of the termini of the fragment was determined with pUC universal primers. The determined sequence was compared to the sequences in the GenBank database (Burks et al., 1992), by using the FASTA algorithm (Pearson \& Lipman, 1988). Sequences derived with forward and reverse primers were $100 \%$ identical with ORF376 and $n i k A$, respectively (Sofia $e t$ al., 1994). ORF376 and the $n i k A$ gene are situated close to each other in the $76.0-81.5 \mathrm{~min}$ region of the $E$. coli chromosome. This region has been sequenced completely by the E. coli Genome Project (Sofia et al., 1994). The only entire ORFs present both in pLH26 and pLH27 are ORF376 and ORF195 (Fig. 2). To see which of them was responsible for complementation, we constructed plasmids pLH29, pLH30 and pLH31. pLH29 carried both ORFs, whereas pLH30 contained only ORF376 and pLH31 only ORF195 (Fig. 2). Plasmids pLH29 and pLH31, but not pLH30, completely reverted the antibiotic-supersensitive phenotype and the thermosensitivity of LH530 (Table 2). The lipid A/ phospholipid ratio was similarly restored by pLH26, pLH29 and pLH31, but not by pLH30 (Fig. 1). These results indicate that ORF195 complemented the defect in LH530. Unrelated supersensitive E. coli mutants, SM101 $\left(l_{p} x A\right)$ or CDH23-213 $\left(l_{p} x D\right)$ were not reverted by pLH31 (Table 2 ).

\section{ORF195 isolated from JM105 or LH530 in a multi-copy plasmid reverts the mutant phenotype but low-copy expression is insufficient}

As shown above, pLH31, carrying the wild-type ORF195 of $E$. coli JM105 in a $1.7 \mathrm{~kb}$ PstI-PstI fragment, was effective in the complementation of the phenotype of 


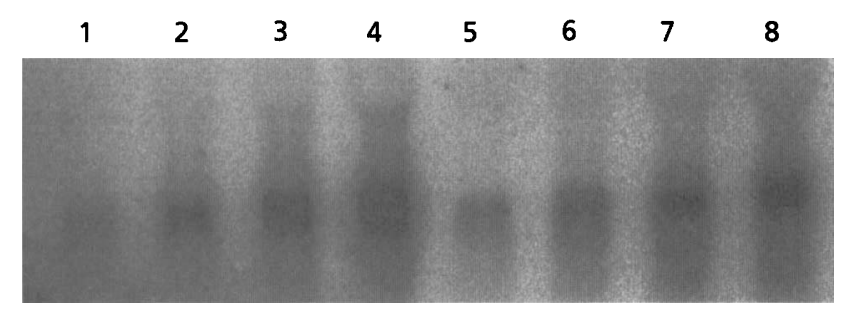

Fig. 3. Northern analysis of ORF195 expression. Total RNA was isolated from exponentially growing cells at $37^{\circ} \mathrm{C}$. Lanes 1-4: $2 \cdot 5,5,10$ and $15 \mu \mathrm{g}$ RNA, respectively, from JM105. Lanes 5-8: $2 \cdot 5,5,10$ and $15 \mu \mathrm{g}$ RNA, respectively, from LH530. The blot was probed with a 300 bp EcoRV-Hpal ORF195-specific probe, and imaged in a Bio-imagins analyser.

LH530. However, the multi-copy plasmid pLH32 that carried ORF195 from the supersensitive mutant strain LH530 was also effective (Table 2). To determine the complementation ability of ORF195 in a low-copy plasmid, we cloned the $2.4 \mathrm{~kb}$ fragment containing ORF376 and ORF195 both from the wild-type and from the mutant strain into a low-copy vector pACYC184. Fragments made blunt-ended were inserted into the EcoRV site of the vector. The resulting plasmids were named pLH36 and pLH37. They were introduced into LH530 and sensitivity to antibiotics was tested. With both plasmids, complementation was good at $28^{\circ} \mathrm{C}$ (data not shown) and partial at $37^{\circ} \mathrm{C}$ (Table 2). Neither could restore the ability of LH530 to grow at $42^{\circ} \mathrm{C}$.

\section{Nucleotide sequence of the wild-type and mutant ORF195}

We sequenced the complete $2.0 \mathrm{~kb} S p h \mathrm{I}-\mathrm{Bg} \mathrm{II}$ insert of pLH31 in both directions, using universal primers and oligonucleotides. This insert contains most of ORF376 and the entire ORF195 of the wild-type strain JM105. The sequence was $100 \%$ identical to the published sequence (Sofia et al., 1994). The corresponding restriction fragment derived from the mutant, LH530, was also $100 \%$ identical.

\section{Transcript analysis}

To determine whether the transcription level of ORF195 was affected in LH530, we performed Northern blot analysis with an ORF195-specific probe using 2.5, 5, 10 and $15 \mu \mathrm{g}$ total RNA isolated from JM105 and LH530 (Fig. 3).The transcription level of ORF195, quantified as described in Methods, was about two times lower in LH530 than in the wild-type. This, however, could not be entirely responsible for the pleiotropic phenotypic properties of LH530.

\section{DISCUSSION}

Thermosensitive, antibiotic-supersusceptible mutants are valuable in studying $O M$ structures and functions. We wanted to isolate a new set of such mutants to reveal missing parts in the biosynthesis of lipid A. Our strategy was to enrich for fusidic-acid-supersensitive mutants in the presence of penicillin after mutagenization of $E$. coli $\mathrm{K}-12$ by diethyl sulfate. In this way we isolated several mutants that displayed a reduced rate of lipid A synthesis.

One of these mutants, LH530, was shown to be extremely sensitive to a set of hydrophobic antibiotics and large hydrophilic antibiotics that are believed to traverse the $O M$ via the hydrophobic pathway of diffusion. This pathway is practically closed in wild-type strains, but open in certain OM mutants, such as the deep-rough heptose-deficient LPS mutants and lipid A biosynthesis mutants of $E$. coli and $S$. typhimurium (Nikaido, 1990; Nikaido \& Vaara, 1987; Hirvas et al., 1991a; Vuorio \& Vaara, 1992a, b).

LH530 was thermosensitive and synthesized reduced amounts of lipid A at $37^{\circ} \mathrm{C}$ and $42^{\circ} \mathrm{C}$. These properties, as well as antibiotic supersensitivity, are also shown by E. coli and S. typhimurium strains harbouring mutations in the lipid A biosynthesis genes $l p x A$ and $l p x D$ (Galloway \& Raetz, 1990; Hirvas et al., 1991a; Helander et al., 1992, 1993; Vuorio \& Vaara, 1992b). However, the antibiotic sensitivity of LH530 was not reverted by $l p x A$ and $l p x D$ indicating that it did not harbour mutations in these genes.

At $28^{\circ} \mathrm{C}$ and $37^{\circ} \mathrm{C}$ some cells of LH530 grew as filaments thus resembling the $E$. coli strains $l p x C$ (Normark et al., 1969) and btrB (Karow \& Georgopoulos, 1991, 1992; Karow et al., 1991). Recently the $h$ trB strain has been shown to be deficient in one of the late acyltransferases (the lauroyl transferase) of lipid A (Clementz et al., 1995; Lee et al., 1995). The other late acyltransferase, specific for myristic acid, is encoded by the $m s b B$ gene (Karow \& Georgopoulos, 1992; Clementz et al., 1995; Somerville et al., 1996). Mass spectrometric analyses have shown that the lipid A of both $h t r B$ and $m s b B$ mutants contains less myristic acid and lauric acid, respectively, than does the wild-type lipid A (Somerville et al., 1996). In gas chromatographicmass spectrometric studies we could not detect any change in the fatty acid composition of lipid A of LH530 at $28^{\circ} \mathrm{C}$ or $37^{\circ} \mathrm{C}$ compared with that of the parent strain (data not shown). Neither could we detect any lipid A precursors in the mutant. However, no precursors have been found in the $l p x A$ or $l p x D$ mutants either (Galloway \& Raetz, 1990; Helander et al., 1992, 1993).

The defect of LH530 was reverted by multiple copies of ORF195. According to the analysis of the sequence data, ORF195 encodes a slightly acidic protein (pI 5.6) with a molecular mass of $21 \cdot 8 \mathrm{kDa}$ (Sofia et al., 1994). The protein has no amino-terminal signal sequence and no long hydrophobic stretches, suggesting that it may be present in the cytoplasm. ORF195 is not preceded by a Shine-Dalgarno sequence. Most probably it is transcribed from the promoter of ORF376, the gene immediately upstream, as no other putative promoter sequences are present. It is possible that the products of 
this operon are regulated together and may also function together. Interestingly, in ORF376 there are several imperfect hexapeptide motifs, characteristic of certain acyl- or acetyltransferases (Vaara, 1992; Vuorio et al., 1994). Immediately $111 \mathrm{bp}$ downstream of the stop codon of ORF195 are the genes for nickel transport, nikA, nikb, nikC, nikD and nikE (Sofia et al., 1994).

When compared with protein sequences in the SWISSPROT database, the deduced amino acid sequence of ORF195 showed the best match with Synechocystis sp. hypothetical protein (ORF246; Kotani et al., 1994); Haemophilus influenzae hypothetical protein (ORF235); a protein encoded by the lpa-14 gene of Bacillus subtilis RB14 (Huang et al., 1993), a possible regulator of the biosynthesis of the lipopeptide antibiotics iturin A and surfactin; and with HetI protein, a possible regulator of growth and development of Anabaena sp. (Black \& Wolk, 1994). These, furthermore, show homology with proteins encoded by the $s f p$, $p s f-1$, orf $X$ and entD genes from $B$. subtilis, Bacillus pumilus, Bacillus brevis and E. coli, respectively. The function of Sfp and PSF-1 has been suggested to be in the regulation of surfactin biosynthesis or its secretion (Morikawa et al., 1992; Nakano et al., 1992), while EntD has been suggested to be involved in the production or secretion of the peptidic siderophore enterobactin (Armstrong et al., 1989; Grossman et al., 1993). The function of the orf X product is not known, but it is located in an operon involved in the biosynthesis of the cyclic lipopeptide gramicidin (Krätzschmar et al., 1989). Thus, betI affects heterocyst formation, lpa-14, sfp and $p s f-1$ the synthesis or secretion of lipopeptide antibiotics and entD siderophore secretion. Common to all these functions is that they are induced under nutrient deprivation. However, the homology of the ORF195 product with the $l p a-14$ gene product and HetI is relatively low, 37.7\% identity in an 106 amino acid overlap and $29 \cdot 2 \%$ identity in an 154 amino acid overlap, respectively.

Interestingly, a perfect match with a six amino acid long consensus sequence, FNI [L]SHS, is present in ORF195 of $E$. coli, SFP and LPA-14 of B. subtilis, ORF235 of $H$. influenzae, ORFX of B. brevis, HetI of Anabaena sp, and PSF-1 of B. pumilus. The entD gene product of $E$. coli and ORF246 of Synechocystis sp. have sequences that partially match the consensus, GSISHCG and FNVAHSG, respectively. Whether this consensus indicates related functions of these proteins remains to be elucidated. The modification of the histidine residue in the consensus region of ORF195 is underway in our laboratory.

According to the sequencing data, ORF195 in LH530 does not harbour any mutations. This is confirmed by the similar complementation ability of ORF195 isolated from either JM105 or LH530. Thus, ORF195 seems to suppress a defect caused by some other gene. The suppression is accessed only if ORF195 is expressed in a multi-copy plasmid. Whether ORF195 is a $m s b A$ - or accBC-like suppressor of the $h t r B$ mutant (Karow et al.,
1992; Karow \& Georgopoulos, 1993) could be determined by suitable complementation studies. We are currently searching an $E$. coli gene bank for the gene corresponding to the one mutated in LH530. This gene may also be lethal when expressed from a multi-copy plasmid, and thus the preparation of a low-copy vector gene bank is being considered.

\section{ACKNOWLEDGEMENTS}

We thank Birgit Kuusela for excellent technical assistance and Helena Mäkelä, Pertti Koski, Suvi Taira and Timo Vaara for helpful discussions. This study was supported by Grant 8404 from the Academy of Finland and by Sigrid Juselius Foundation.

\section{REFERENCES}

Armstrong, S. K., Pettis, G. S., Forresyer, L. J. \& Mclntosh, M. A. (1989). The Escherichia coli enterobactin biosynthesis gene, entD: nucleotide sequence and membrane localization of its protein product. Mol Microbiol 3, 757-766.

Black, T. A. \& Wolk, C. P. (1994). Analysis of a $\mathrm{Het}^{-}$mutation in Anabaena sp. strain PCC 7120 implicates a secondary metabolite in the regulation of heterocyst spacing. J Bacteriol 176, 2282-2292.

Boman, H. G \& Monner, D. A. (1975). Characterization of lipopolysaccharides from Escherichia coli K-12 mutants. J Bacteriol 121, 455-464.

Burks, C., Cinkosky, M. J., Fischer, W. M., Gilna, P., Hayden, J. E., Keen, G. M., Kelly, M., Kristofferson, D. \& Lawrence, J. (1992). GenBank. Nucleic Acids Res 20, 2065-2069.

Clementz, T., Bednarski, J. \& Raetz, C. R. H. (1995). Escherichia coli genes encoding KDO dependent acyltransferases that incorporate laurate and myristate into lipid A. In Abstracts of the Annual Meeting of the American Society for Biochemistry and Molecular Biology, May 21-25 1995, vol. 9, p.1311. Federation of American Societies for Experimental Biology.

Coleman, W. G. \& Leive L. L. (1979). Two mutations which affect the barrier function of the Escherichia coli K-12 outer membrane. J Bacteriol 139, 899-910.

Galloway, S. \& Raetz C. R. H. (1990). A mutant of Escherichia coli defective in the first step of endotoxin biosynthesis. $J$ Biol Chem 265, 6394-6402.

Grossman, T. H., Tuckman, M., Ellestad, S. \& Osburne, M. (1993). Isolation and characterization of Bacillus subtilis genes involved in siderophore biosynthesis : relationship between B. subtilis $s \mathrm{fp}^{0}$ and Escherichia coli entD genes. J Bacteriol 175, 6203-6211.

Hanahan, D. (1983). Studies on transformation of Escherichia coli with plasmids. $J \mathrm{Mol}$ Biol 166, 557-580.

Helander, I. M., Hirvas, L., Tuominen, J. \& Vaara, M. (1992). Preferential synthesis of heptaacyl lipopolysaccharide by the ssc permeability mutant of Salmonella typhimurium. Eur J Biochem 204, 1101-1106

Helander, I. M., Lindner, B., Seydel, U. \& Vaara, M. (1993). Defective biosynthesis of the lipid A component of temperaturesensitive firA (omsA) mutant of Escherichia coli. Eur J Biochem 212, 363-369.

Hirvas, L., Koski, P. \& Vaara, M. (1991a). Identification and sequence analysis of the gene mutated in the conditionally lethal outer membrane permeability mutant SS-C of Salmonella typhimurium. EMBO J 10, 1017-1023. 
Hirvas, L., Koski, P. \& Vaara, M. (1991b). The ompH gene of Yersinia enterocolitica: cloning, sequencing, expression, and comparison with known enterobacterial ompH sequences. $J$ Bacteriol 173, 1223-1229.

Huang, C.-C., Ano, T. \& Shoda, M. (1993). Nuclotide sequence and characteristics of the gene, lpa-14, responsible for biosynthesis of lipopeptide antibiotics iturin A and surfactin from Bacillus subtilis RB14. J Ferment Bioeng 6, 445-450.

Karow, M. \& Georgopoulos, C. (1991). Sequencing, mutational analysis, and transcriptional regulation of the Escherichia coli htrB gene. Mol Microbiol 5, 2285-2292.

Karow, M. \& Georgopoulos, C. (1992). Isolation and characterization of the Escherichia coli $m s b B$ gene, a multicopy suppressor of null mutations in the high-temperature requirement gene htrB. J Bacteriol 174, 702-710.

Karow, M. \& Georgopoulos, C. (1993). The essential Escherichia coli $m s b A$ gene, a multicopy suppressor of null mutations in the $h t r B$ gene, is related to the universal conserved family of ATPdependent translocators. Mol Microbiol 7, 69-79.

Karow, M., Fayet, O., Cegielska, A., Ziegelhoffer, T. \& Georgopoulos, C. (1991). Isolation and characterization of the Escherichia coli htrB gene, whose product is essential for bacterial viability above $33^{\circ} \mathrm{C}$ in rich media. $J$ Bacteriol 173, 741-750.

Karow, M., Fayet, O. \& Georgopoulos, C. (1992). The lethal phenotype caused by null mutations in the Escherichia coli btrB gene is suppressed by mutations in the $a c c B C$ operon, encoding two subunits of acetyl coenzyme A carboxylase. J Bacteriol 174, 7407-7418.

Koski, P. \& Vaara, M. (1991). Polyamines as constituents of the outer membranes of Escherichia coli and Salmonella typhimurium. J Bacteriol 173, 3695-3699.

Koski, P., Rhen, M., Kantele, J. \& Vaara, M. (1989). Isolation, cloning, and primary structure of a cationic $16-\mathrm{kDa}$ outer membrane protein of Salmonella typhimurium. J Biol Chem 264, 18973-18980.

Kotani, H., Kaneko, T., Matsubayashi, T., Sato, S., Sugiura, M. \& Tabata, S. (1994). A physical map of the genome of a unicellular Cyanobacterium cynechocystis sp. strain PCC6803. DNA Res 1, 303-307.

Krătzschmar, J., Krause, M. \& Marahiel, M. A. (1989). Gramicidin $\mathrm{S}$ biosynthesis operon containing the structural genes $g r s A$ and $g r s B$ has an open reading frame encoding a protein homologous to fatty acid thioesterases. J Bacteriol 171, 5422-5429.

Laemmli, U. K. (1970). Cleavage of structural proteins during the assembly of the head of bacteriophage T4. Nature 227, 680-685.

Lee, N.-G., Sunshine, M. G., Engstrom, J. J., Gibson, B. W. \& Apicella, M. A. (1995). Mutation of the htrB locus of Haemophilus influenzae nontypable strain 2019 is associated with modifications of lipid A and phosphorylation of the lipo-oligosaccharide. $J$ Biol Chem 270, 27151-27159.

Ma, D., Cook, D. N., Alberti, M., Pon, N. G., Nikaido, H. \& Hearst, J. E. (1995). Genes $a c r A$ and $a c r B$ encode a stress induced efflux system of Escherichia coli. Mol Microbiol 16, 45-55.

Morikawa, M., Ito, M. \& Imanaka T. (1992). Isolation of new surfactant producer Bacillus pumilus A-1, and cloning and nucleotide sequence of the regulator gene psf-1.J Ferment Bioeng 74, 255-261.

Nakano, M. M., Corbell, N., Benson, J. \& Zuber, P. (1992). Isolation and characterization of sfp: a gene that functions in the production of the lipopeptide biosurfactant, surfactin, in Bacillus subtilis. Mol Gen Genet 232, 313-321.
Nikaido, H. (1990). Permeability of the lipid domains of bacterial membranes. Membrane transport and information storage. In Advances in Membrane Fluidity, vol. 4, pp. 165-190. Edited by R. C. Aloia, C. C. Curtain \& L. M. Gordon. New York: Alan R. Liss.

Nikaido, H. \& Nakae, T. (1979). The outer membrane of gramnegative bacteria. Adv Microb Physiol 20, 163-250.

Nikaido, H. \& Vaara, M. (1985). Molecular basis of bacterial outer membrane permeability. Microbiol Rev 49, 1-32.

Nikaido, H. \& Vaara, M. (1987). Outer membrane. In Escherichia coli and Salmonella typhimurium: Cellular and Molecular Biology, pp. 3-22. Edited by F. C. Neidhardt, J. L. Ingraham, K. Brooks Low, B. Magasanik, M. Schaechter \& H. E. Umbarger. Washington, DC: American Society for Microbiology.

Normark, S., Boman, H. G. \& Mattson, E. (1969). Mutant of Escherichia coli with anomalous cell division and ability to decrease episomally and chromosomally mediated resistance to ampicillin and several other antibiotics. J Bacteriol 92, 1334-1342.

Pearson, W. R. \& Lipman, V. (1988). Improved tools for biological sequence comparison. Proc Natl Acad Sci USA 85, 2444-2448.

Raetz, C. R. H. (1990). Biochemistry of endotoxins. Annu Rev Biochem 59, 129-170.

Raetz C. R. H. (1993). Bacterial endotoxins: extraordinary lipids that activate eucaryotic signal transduction. J Bacteriol 175, 5745-5753.

Sambrook, J., Fritsch, E. F. \& Maniatis, T. (1989). Molecular Cloning: a Laboratory Manual, 2nd edn. Cold Spring Harbor, NY: Cold Spring Harbor Laboratory.

Schnaitman, C. A. \& Klena J. D. (1993). Genetics of lipopolysaccharide biosynthesis in enteric bacteria. Microbiol Rev 57, 655-682.

Sofia, H. J., Burland, V., Daniels, D. L., Plunkett, G., III \& Blattner, F. R. (1994). Analysis of the Escherichia coli genome. V. DNA sequence of the region from 76.0-81.5. Nucleic Acids Res 22, 2576-2586.

Somerville, J. E., Cassiano, L., Bainbridge, B., Cunningham, M. D. \& Darveau, R. P. (1996). A novel Escherichia coli lipid A mutant that produces an antiinflammatory lipopolysaccharide. $J$ Clin Immunol 97, 359-365.

Sukupolvi, S., Vaara, M., Helander, I. M., Viljanen, P. \& Makelă, P. H. (1984). New Salmonella typhimurium mutants with altered outer membrane permeability. J Bacteriol 159, 704-712.

Tamaki, S., Sato, T. \& Matsuhashi, M. (1971). Role of lipopolysaccharides in antibiotic resistance and bacteriophage adsorption of Escherichia coli K-12. J Bacteriol 105, 968-975.

Tsuruoka, T., Ito, M., Tomioka, S., Hirata, A. \& Matsuhashi, M. (1988). Thermosensitive omsA mutation of Escherichia coli that causes thermoregulated release of periplasmic proteins. $J$ Bacteriol 170, 5229-5235.

Vaara, M. (1992). Eight bacterial proteins, including UDP-Nacetylglucosamine acyltransferase $(\mathrm{LpxA})$ and three other transferases of Escherichia coli, consist of a six-residue periodicity theme. FEMS Microbiol Lett 97, 249-254.

Vaara, M. (1993). Antibiotic-supersusceptible mutants of Escherichia coli and Salmonella typhimurium. Antimicrob Agents Chemother 37, 2255-2260.

VonGabain, A., Belasco, J. G., Schottel, J. L., Chang, A. C. Y. \& Cohen, S. N. (1983). Decay of mRNA in Escherichia coli: investigation of the fate of specific segments of transcripts. Proc Natl Acad Sci USA 80, 653-657.

Vuorio, R. \& Vaara, M. (1992a). The lipid A biosynthesis mutation 
IpxA2 of Escherichia coli results in drastic antibiotic supersusceptibility. Antimicrob Agents Chemother 36, 826-829.

Vuorio, R. \& Vaara, M. (1992b). Mutants carrying conditionally lethal mutations in outer membrane genes oms $A$ and firA (ssc) are phenotypically similar, and $o m s A$ is allelic to firA. J Bacteriol 174, 7090-7097.

Vuorio, R. \& Vaara, M. (1995). Comparison of the phenotypes of the $l p x A$ and $l p x D$ mutants of Escherichia coli. FEMS Microbiol Lett 134, 227-232.

Vuorio, R., Hărkönen, T. \& Vaara, M. (1994). The novel hexapeptide motif found in the acyltransferases LpxA and LpxD of lipid A biosynthesis is conserved in various bacteria. FEBS Lett 337, 289-292.

Wilkinson, R. G., Gemski, P., Jr \& Stocker, B. A. D. (1972). Non- smooth mutants of Salmonella typhimurium: differentiation by phage sensitivity and genetic mapping. J Gen Microbiol 70, 527-554.

Yanisch-Perron, C., Vieira, J. \& Messing, J. (1985). Improved M13 phage cloning vectors and host strains: nucleotide sequences of the M13mp18 and pUC19 vectors. Gene 33, 103-119.

Young, K., Silver, L. L., Bramhill, D., Caceres, C. A., Stachula, S. A., Shelly, S. E., Raetz, C. R. H. \& Anderson, M. S. (1993). The second step of lipid A biosynthesis, UDP-3-o-acyl-GlcNAc deacetylase, is encoded by the pleiotropic permeability/cell division gene envA of E. coli. FASEB J 7, 1268.

Received 24 June 1996; revised 19 August 1996; accepted 27 August 1996. 